\title{
Methodological features of graphic tools
}

\author{
Anvar Haydarov \\ Associate professor of \\ English linguistics department \\ Foreign languages faculty \\ Bukhara State University
}

\begin{abstract}
This article discusses graphic stylistic devices in the English and Uzbek languages, the "additional" meanings expressed in them. Some similarities and differences between graphic devices in English and Uzbek have been analyzed on the basis of examples from literary works in both languages. Attention is also paid to the fact that graphic stylistic devices are represented by various punctuation marks.

Key words: phonostylistics, connotation, stylistic devices, graphic stylistics, phonography, italics, capital letters,
\end{abstract} colon, literary text, punctuation.

\section{I.Introduction}

Graphic stylistics consists of the expressive means of expressing in writing the emotions expressed through intonation and stress in oral speech. The use of graphostylistic tools in fiction is a demonstration of the possibilities of the author's strategy. To achieve this goal, the author constructs a series of different phonographic methods used in the texts of the work of art. From the phonographic methodological tools in English literature, L.F. Baum, L. Caroll, A.A. Miln,; D.Gyorber, R. Dal was widely used in their classical works.

In Russian linguistics, L.I. Eremina notes that graphostylistic tools are extensive in language and writes: "In artistic speech, it is important to write the vowels and consonants in different forms, to use more than one punctuation mark in one place, as well as to use different punctuation marks."

\section{II.Literature review}

Phonographic methods in Uzbek linguistics It is described in detail in Yakhshieva's dissertation.

The phonographic methodology, the scholar writes, is a branch of general methodology that studies and teaches the stylistic possibilities and features of pronunciation in written speech, ways and means, as well as the graphical (spelling) stylistic possibilities and features of written speech in dialectical unity.

The phonographic methodology also does not have its own separate unit. It serves to convey the emotionalexpressive color of the phonetic and graphic means of language.

Graphic stylistics focuses on the typological features of the text, including punctuation, font, size and placement of graphemes. Foreign scholars have also expressed their views on this issue. In particular, Norgard argues that typographic features help to explore and explore the spiritual potential of visual aspects of printed oral speech in the literature, while linguist Lich describes graphic methodological tools as belonging to the writing system today: punctuation, paragraph, and space. Bilal and Chimas, on the other hand, recognize that graphic means deal with the formation, structure, and punctuation of a system in speech.

\section{III.Analysis}

Graphic changes not only reflect the specific features of pronunciation, but are also used to express the intensity of the emphasis, emphasizing the words that are stressed. Pure graphic tools include paragraph breaks, uppercase and lowercase letters, letters of different sizes, italicization of certain words and text passages, step by step lines in poetry, omission of one line of poetry, writing dots in its place, punctuation for methodological purposes.

Now let's think about some of these graphical tools. The most effective of the graphic stylistic tools is to write words in italics. Often epigraphs, prose works, quotations, words borrowed from other languages, the name of works of art are written in italics, and it indicates that those words are of particular importance. In works, English auxiliary words, auxiliary verbs, rhymes are often written in italics.

For example:

-"Bella!"

-"Yes. Master John"

-"Do let's have tea, under the oak tree when they came; I know, they'd like it best.

-"You mean you'd like it best"

Little John considered

-No, they would, to please me.

\section{(J. Galsworthy "Awakening")}

When auxiliary verbs will and would are used to express a continuous action, they come without stress and are written as usual. But when used in the accented case, they represent the allegory and are written in italics. 
For example: ... his liver was a little constricted and his nerves rather on edge. His wife always out when she was in Town and his daughter would flibberty -gibbet all over the place. (J. Galsworthy "Awakening”).

Auxiliary verbs are also written in italics to reinforce affirmation:

-Olwen (smiling at him affectionately):

You are a baby, Robert.

(I.B. Priestly "Dangerous Corner").

As mentioned above, words learned from other languages are also written in italics. In particular, in the following sentence, words from the French language are written in italics:

-Bonjour la compagnie he said cheerfully. "I've brought you a present".

Italicization of words is found not only in prose, but also in poetry.

(S.W. Maugham, Stories, “The Unconquered” P:45)

In Thomas Steriz Eliot's poem “A Cooking Egg," the 30-year-old protagonist's attitude toward youth is expressed in bitter irony. The image of the room is reminiscent of the look of Oxford.

For example:

Pipit sat upright in her chair

Some distance from where I was sitting,

Views of Oxford Colleges

Lay on the table with the knitting.

(T.S. Eliot "The Cooking Egg")

When thinking in this area, of course, one must also pay attention to poetics. "The writing of some poetics in artistic speech can be expressed in various graphic forms. Poetry is not any name in an artistic text, but a name that serves to illuminate the creative artistic intention.

Graphic tools are mainly represented in punctuation. Punctuation is used to describe the relationship between the author and the speaker and shows the emotional nature. Punctuation illuminates the rhythmic-melodic aspect of speech. Some information on the methodological features of punctuation recorded by K.Nazarov. In particular, the double use of the same punctuation marks in a row indicates the addition of new content to the sentence.

Questioning and exclamation marks are mainly placed at the end of a sentence and perform an important methodological function. This can be clearly seen in the following example:

George: (savagely) That's good! Oh, yes! And what about you?

Ruth: (off her balance) What about me?

George: What are you doing here? All right, you've had your go at me. But what about yourself?

Ruth: Well?

George: Oh, don’t be so innocent, Ruth. This house! This room! This hideous. God -awful room!

The dash is also important in expressing graphic means, it is used to express emotionally pauses. An emotional pause can sometimes be expressed through multiple points: to finish.

For example: You'd try, I know you'd try. Perhaps ... But he had no idea himself how that sentence was supported

(G. Greene. The Heart of the Matter).

In fiction, in most cases, multiple dots and dashes replace each other.

Obven: Martin didn't shoot himself ...

Freda: Martin didn't -

Obven: Of course he didn't I shot him.

\section{(I.B. Priestley. Dangerous Corner)}

\section{IV.Discussion}

Dash and multi-dot are used to highlight the most important word from a sentence, and it captures the reader's attention. Dashes and multi-dots also serve to fill the meaning.

For example: This is the Hour of Lead -Remembered if outlived.

As Freezing persons, recollect the Snow First -Chill then.

Stupor -then the letting go -

Step-by-step writing of poetic verses creates a pause situation, in which step-by-step poetic verses are separated by commas. The poem "Valley of Happiness" by Hamid Olimjon, a sensitive poet in Uzbek poetry, begins with such stepby-step verses. In doing so, the poet often chooses intonation and rhythmic steps to express his idea in depth, to fully embody the image being praised in the eyes of the reader.

Blue,

$$
\text { blue, }
$$

blue

Green hills from the spring sun

Lands carrying steel rafters 
[Ko'm-ko'k,

blue!

ko'm-ko'k,

ko'm-ko'k

Ko'klam quyoshidan ko'kargan qirlar

Po'lat yag'riplarni ko'targan yerlar

ko'm-ko'k!]

Elsewhere in this poem, the intonational integrity has some character:

O Fergana, in difficult times, biting a child on the tongue,

Washing,

combing,

loving,

kissing,

embracing,

hugging.

O mother who brought happiness to puberty!

(H. Olimjon)

[Ey Farg'ona, mushkul kunlar bolasini tilida tishlab,

yuvib,
tarab,

sevib,

o'pib,

quchib,

Ey baxtlarni balog'atga yetkazgan ona!

(H. Olimjon)]

opichlab.

Apparently, by writing the verses of the poem step by step, the poet charms the reader by adapting his heart to his soul.

Another graphic methodological tool is a paragraph.

- "When reading the text, each paragraph is separated by a long pause. It is this pause that concludes the thought in the previous paragraph and prepares you for the transition to the new paragraph. Each paragraph serves a methodological-textual function. It summarizes what is being emphasized, the evidence, or helps to divide it into separate groups." writes E. Qilichev.

For example:

-"Darling, what is it? Has he insulted you again?"

Another graphic methodological tool is to capitalize words.

According to the grammatical rule, the letters are written in capital letters at the beginning and after the dot, but in the middle of the word, the words are deliberately capitalized to indicate stylistic coloring or the effectiveness of a word.

For example: O Music! Sphere -descended maid

Friend of Pleasure, Wisdom's aid!

(W. Collins. The Passions)

If way to the Better there be it eracts

full look at the worst.

(Th. Hardy)

Whole words can be capitalized and read aloud in a separate emotion or aloud.

For example: And there was dead silence

Till at last came the whisper "I didn't kill Henry. NO, NO! Henry surely you cannot blame me. I loved you dearest. (D.H. Laurence. "The Lovely Lady")

In works written in different genres of the Uzbek language, there are various words and phrases written in capital letters, which is one of the graphic methods. They mainly serve to attract the reader's attention to the image, to arouse various emotions.

Talented poet Omon Matchon in his poems "To the Red Book of Nature", "The word Mother" wrote some words in capital letters and used graphostiles:

I wanted to draw a picture of grass,

(Chizgim keldi maysaning rasmin)

I wrote slow that is spring,

(Yozib qo'ydim bahor deb asta)

I went, in Mother's name

(Men jo etdim, Ona nomiga)

Now to the word Mother. 
(Endi Ona so'zi yoniga)

I boldly write: The world.

(Dadil yozib qo'yaman: Dunyo.) (O.Matchon)

Graphic stylistic tools also play an important role by dropping punctuation.

Writing down the dots in a poem is also used to write it in form, to bring it closer to documents, to give it importance, and to give it a solemnity.

For example: Defence of the Islands.

Let these memorials of built stone -music's enduring instrument of many centuries of patient cultivation of the earth of English verse he joined with the memory of this defence of the islands.

Poetic lines can also be written in the form of various figures by dropping a dot from punctuation. The following poem by Estlyn Cemmin is written in the form of a triangle:

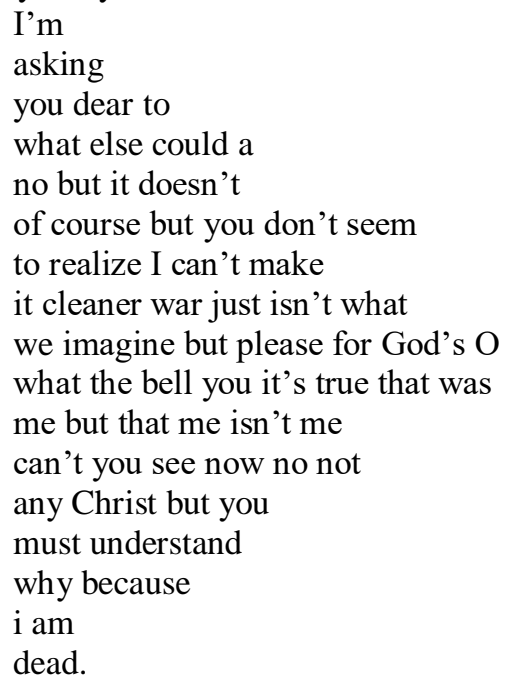

\section{V.Conclusion}

Thus, graphic changes not only reflect the specific features of pronunciation, but are also used to emphasize the stressed words, to express the intensity of the stress. Graphic tools play an important methodological role in writing words in italics, intentionally writing words in capital letters, enclosing the main part of speech in quotation marks, parentheses, commas, question marks or exclamation marks, writing words in hyphens.

\section{References:}

1. Eremina L.I. Graphics as a means of representation in works. L.N. Tolstoy // Sat. stat. Essays on the stylistics of artistic speech. -M .: 1979. -pp. 77-113.

2. Yaxshieva G. Phonographic methodical means in the Uzbek language. Filol. science nomz. diss. -T .: $1997 .-136$ p.

3. Yaxshieva G. Phonographic methodical means in the Uzbek language. -T .: Fan. 1996. -30p.

4. Khudoyberganova D., Andaniyazova D. Annotated dictionary of Uzbek poetics. Turon Zamin Ziyo. -T .: 2016. -p. 46.

5. Nazarov K. Punctuation and written speech. -T .: Fan, 1974. -p. 61.

6. S.Tajibaev A comparative analysis of the biokinematic chain of action games in the technical training of adolescent boxers.Scientific Bulletin, AnSU, Issue 1, 2018. [13.00.00№12] https://xabarnoma.adu.uz/arxiv/2018/2018-1Pages 97-100 7. Volkov L.V. Theory and methodology of children and youth sports. Kiev Olympic literature. 2002 .-- 290 p .;

8. Lip V.P., Kvashuk P.V., Nikitushkin V.G. Individualization of training for young athletes. - Moscow: FiS, 2009 .-- 76 $\mathrm{p}$; https://www.dissercat.com/content/sovershenstvovanie-sistemy-upravleniya-podgotovkoi-sportivnykh-rezervov-vedinoborstvakh

9. The system of training the sports reserve / Under total. Ed. V.G. Nikitushkina - M., $1994 . \quad$-319 p .; https://studfile.net/preview/2899059/page:12/

10. https://www.dissercat.com/content/polifunktsionalnaya-leksicheskaya-edinitsa-k-slovu-i-ee-kontekstnofunktsionalnye-sinonimy

11. S.Tajibaev The effectiveness of the use of movement games in the training of young athletes, Pedagogical skills. Bukhara, 2018, issue 2 [13.00.00№23] Pp. 303-306. 